\title{
UNIVERSITY STUDENTS' STRUGGLES WITH ONLINE LEARNING DURING THE COVID-19 PANDEMIC LOCKDOWN
}

\author{
Esther Chiner ${ }^{1}$, Marcos Gómez-Puerta ${ }^{2}$, Victoria E. García-Vera ${ }^{3}$, \\ \& M. Cristina Cardona-Moltó ${ }^{1}$ \\ ${ }^{I}$ Department of Health Psychology, University of Alicante (Spain) \\ ${ }^{2}$ Department of Developmental Psychology and Teaching, University of Alicante (Spain) \\ ${ }^{3}$ Department of Architecture and Building Technology, Technical University of Cartagena (Spain)
}

\begin{abstract}
As a result of the COVID-19 pandemic that affected most countries during the year 2020, the society had to adapt rapidly to new forms of working in which the Internet has been an essential tool. And so did the higher institutions around the world, which had to move from a face-to-face classroom environment to an online one. The change from traditional learning to online learning was so unexpected that neither the instructors nor the students may have been prepared for it and could have important consequences on students' learning and academic achievement. The purpose of this study was to explore how university students had to struggle with online learning during the COVID-19 pandemic lockdown attending to three aspects: (a) availability and use of electronic devices, (b) personal factors, and (c) teaching factors. A non-experimental study based on a survey design was conducted, in which a convenience sample of 496 undergraduate and graduate students from two different universities located in south eastern Spain participated. The majority of the participants $(66.3 \%)$ had very little or no experience in online learning and $55 \%$ considered that their academic performance was being worse than in face-to-face classes. Findings showed that most of the students had the electronic devices required for online learning (e.g. laptops, earphones, webcams, smartphones), although they mainly used laptops and earphones. They did not have other devices at home such as desktop computers, printers and scanners. The personal factors that most affected their academic performance were family problems and/or responsibilities $(46.6 \%)$, psychological or emotional problems (41.6\%), an inappropriate study environment (41.2\%), and a bad Internet connection $(31.4 \%)$. With regard to teaching factors, students complained of excessive assignments $(82.6 \%)$, lack of lesson explanations $(78.6 \%)$, loss of concentration during synchronous classes (64.3\%), having to learn through the computer screen (58.9\%), and feeling of being abandoned (57.4\%), among others. In sum, university students' struggles with online learning were more related to teaching factors than to personal and material factors. Therefore, higher education institutions and faculty should be prepared to respond to student's needs in different teaching scenarios, and more specifically in online environments, by adapting not only their teaching styles and resources but also the way they interact with students.
\end{abstract}

Keywords: Online learning, higher education, academic performance, COVID-19.

\section{Introduction}

The outbreak of the Coronavirus disease (COVID-19) in China in December 2019 was classified as a global pandemic by the World Health Organization (WHO) in March 2020 (WHO, 2020). From that moment, most countries regulated to follow strict protocols to slow down and prevent the spread of the virus by ordering complete lockdowns and social distancing (Bozkurt \& Sharma, 2020). As a result, businesses and schools closed and were urged to work from home. The world had to adapt to new ways of working, interacting, and learning in which technology became the best ally.

According to the United Nations Educational, Scientific and Cultural Organization (UNESCO), by April 2020, school closures had affected 172 countries, and $84 \%$ of students of all educational stages (from preschool to higher education) moved from traditional face-to-face classes to different modalities of distance or remote learning (UNESCO, 2020). Higher education institutions had to accommodate their technology and teaching practices in record time when, in many cases, neither the institutions were technologically prepared for that change nor did the instructors have the digital competence to meet the 
new demands (Amhag, Hellström, \& Stigmar, 2019; Portillo, Garay, Tejada, \& Bilbao, 2020). Although many universities provided teachers with guidelines, tools, and training on online teaching, the urgency of the situation left in educators' hands how they accommodated their classes to distance learning. Subsequently, university students had to face not only a new modality of learning but also different methodologies and instructional strategies depending on teachers' preferences and digital skills.

Traditionally, the new generation of students have been considered "digital natives" since they have grown up in the digital age and in close contact with technology and the Internet (Cabero-Almenara \& Llorente-Cejudo, 2020). However, research has shown that students are not that competent when they have to deal with educational technology (Álvarez-Flores \& Núñez-Gómez, 2019; Bossolasco, Chiecher, \& Dos Santos, 2020). Institutions and faculty may have failed to understand this fact, expecting university students to be "naturally" prepared for the shift to online learning and avoiding their needs, difficulties and competences to respond to their learning demands adequately.

In this context of uncertainty, it is key to understand students' learning experiences during the lockdown to provide high-quality education in emergency times in the future.

\section{Objectives}

The purpose of this study was to explore how university students had to struggle with online learning during the COVID-19 pandemic lockdown in 2020 in terms of: (a) availability and use of electronic devices, (b) personal factors, and (c) teaching factors. It also aimed to determine which factors (personal vs teaching factors) affected students the most.

\section{Methods}

\subsection{Design}

A cross-sectional survey design was conducted to explore students' experiences with online learning during the COVID-19 pandemic lockdown. This research design has the advantage to provide information about individuals' opinions, attitudes or practices at one point in time (Creswell, 2015).

\subsection{Participants}

A convenience sample of 496 undergraduate and graduate students from two different universities in south eastern Spain participated in the study. Students' age ranged between 18 and 49 years old $(M=23.77, S D=5.69)$ and the majority were female students $(85.1 \%)$. Most of the participants had little or no experience in online learning (66.4\%). With regard to their academic performance, $54 \%$ of the students expected lower outcomes compared with traditional learning.

\subsection{Instruments}

An electronic questionnaire was designed to collect data about students' perceptions of online learning during the lockdown derived from the COVID-19 pandemic. The instrument comprised six sections: (a) sociodemographic information, (b) usage of electronic devices, (c) use and utility of teaching materials and resources, (d) use and utility of teaching strategies, (e) use and utility of online evaluation resources, and (f) difficulties encountered during online learning. Participants had to respond to a 5-point Likert scale that ranged from $1=$ Never to $5=$ Always. This paper presents the main results related to the use of electronic devices ( 9 items) and the inconveniences of learning online in terms of personal factors (11 items) and teaching factors (15 items). The instrument showed good internal consistency for the overall scale $(\alpha=.94)$ and for both sections presented in this work [use of electronic devices $(\alpha=.66)$; difficulties encountered $(\alpha=.90)]$.

\subsection{Procedure}

The electronic questionnaire was disseminated via email and the noticeboard of the university online platform among students enrolled in Education programmes and Architecture of two different universities. Informed consent was requested before the participation in the study. The survey started with general information about the purpose of the survey, and students had to respond to the questions attending to their overall experience in online learning during the lockdown and not to a specific subject. Time to complete the survey was 10-15 minutes and the survey remained open during the last two months of the second semester (from mid-May to mid-July). 


\subsection{Data analyses}

Descriptive analyses were carried out to meet the purpose of the study (i.e. percentages, means, standard deviations). To explore differences between personal and teaching factors a paired-samples t-test was performed.

\section{Results}

\subsection{Availability and use of electronic devices}

Overall, students had the necessary electronic devices to follow online learning adequately (Table 1). The primary tools used for the classes were laptops $(94.3 \%)$ and headphones or speakers (70.7\%). Half of the participants barely used the webcam (52.1\%) and only one third used the microphone frequently $(34.6 \%)$. Other devices such as smartphones $(48.5 \%)$ and printers $(46.3 \%)$ were used to a certain extent.

Table 1. Frequency of use of electronic devices for online learning during the COVID-19 pandemic.

\begin{tabular}{|l|l|l|l|l|l|l|}
\hline & & & Never / rarely & Sometimes & Often / Always & Do not have \\
\hline & $M$ & $S D$ & $\%$ & $\%$ & $\%$ & $\%$ \\
\hline Webcam & 2.52 & 1.23 & 52.1 & 27.0 & 20.9 & 5.2 \\
\hline Microphone & 3.07 & 1.18 & 32.9 & 32.5 & 34.6 & 2.6 \\
\hline Headphones / speakers & 3.92 & 1.29 & 15.7 & 13.6 & 70.7 & 2.2 \\
\hline Desktop computer & 2.35 & 1.61 & 61.9 & 8.9 & 29.2 & 59.3 \\
\hline Laptop & 4.75 & 0.74 & 3.5 & 2.2 & 94.3 & 1.0 \\
\hline Tablet & 2.39 & 1.47 & 56.1 & 17.4 & 26.5 & 53.6 \\
\hline Smartphone & 3.27 & 1.45 & 32.6 & 18.9 & 48.5 & 2.8 \\
\hline Printer & 3.21 & 1.44 & 31.1 & 22.7 & 46.3 & 35.1 \\
\hline Scanner & 2.30 & 1.36 & 58.2 & 20.0 & 21.8 & 42.1 \\
\hline
\end{tabular}

\subsection{Struggles with online learning due to personal factors}

With regard to the personal factors affecting online learning during the COVID-19 pandemic lockdown, students reported family responsibilities and concerns $(46.6 \%)$, the difficulty to adapt to online learning (46\%) and psychological or emotional problems (41.5\%). To a lesser extent, they complained about excessive workload not related to online learning $(32.3 \%)$ and bad Internet connection $(31.5 \%)$. Details are displayed in Table 2.

Table 2. Personal factors affecting online learning during the COVID-19 pandemic.

\begin{tabular}{|l|l|l|l|l|l|}
\hline & & & Never / rarely & Sometimes & Often / Always \\
\hline & $M$ & $S D$ & $\%$ & $\%$ & $\%$ \\
\hline Family concerns or responsibilities & 3.31 & 1.32 & 26.4 & 27.0 & 46.6 \\
\hline Health problems & 2.11 & 1.27 & 67.5 & 15.3 & 17.1 \\
\hline Psychological problems & 3.02 & 1.47 & 36.5 & 22.0 & 41.5 \\
\hline Excessive workload (not related to online learning) & 2.76 & 1.42 & 44.6 & 23.2 & 32.3 \\
\hline Inappropriate study environment & 2.96 & 1.49 & 41.5 & 17.3 & 41.1 \\
\hline Lack of specific devices & 2.11 & 1.32 & 66.7 & 15.5 & 17.7 \\
\hline Sharing electronic devices & 2.16 & 1.43 & 65.5 & 12.1 & 22.4 \\
\hline Lack of specific software & 2.20 & 1.38 & 63.9 & 15.1 & 21.0 \\
\hline Bad Internet connection & 2.62 & 1.48 & 50.2 & 18.3 & 31.5 \\
\hline Difficulties to adapt to online learning & 3.29 & 1.31 & 26.8 & 27.2 & 46.0 \\
\hline $\begin{array}{l}\text { Wasting time by using the computer for other } \\
\text { purposes than learning }\end{array}$ & 2.67 & 1.38 & 50.4 & 19.8 & 29.8 \\
\hline
\end{tabular}

\subsection{Struggles with online learning due to teaching factors}

Concerning teaching factors affecting students' online learning (Table 3), they mainly struggled with the excessive autonomous learning $(82.75 \%)$, the lack of lesson explanations $(78.6 \%)$ and the loss of concentration during live streaming classes (64.3\%). They also complained about the teachers' response during online learning such as feeling abandoned by them $(57.5 \%)$ as well as shorter lesson explanations and no feedback of the activities carried out (50.8\%). 
Table 3. Teaching factors affecting online learning during the COVID-19 pandemic.

\begin{tabular}{|l|l|l|l|l|l|}
\hline & & & Never / rarely & Sometimes & Often / Always \\
\hline Feeling abandoned by teachers & $M$ & $S D$ & $\%$ & $\%$ & $\%$ \\
\hline Insufficient information on week assignments & 3.60 & 1.19 & 17.7 & 24.8 & 57.5 \\
\hline Excessive autonomous learning & 3.04 & 1.28 & 34.3 & 28.0 & 37.7 \\
\hline Lack of lesson explanations & 4.20 & 0.98 & 7.5 & 9.9 & 82.7 \\
\hline Lack of teaching materials & 3.41 & 1.30 & 6.7 & 14.7 & 78.6 \\
\hline Difficulty to contact teachers & 2.62 & 1.27 & 50.0 & 25.0 & 49.6 \\
\hline Learning through a computer screen & 3.60 & 1.40 & 23.4 & 25.8 & 24.2 \\
\hline Loss of concentration during streaming classes & 3.76 & 1.36 & 22.0 & 17.7 & 58.9 \\
\hline Low quality of live streaming classes & 3.47 & 1.35 & 24.6 & 23.8 & 51.6 \\
\hline $\begin{array}{l}\text { Shorter lesson explanations and no feedback } \\
\text { about the results/solutions of activities }\end{array}$ & 3.36 & 1.42 & 28.8 & 20.4 & 50.8 \\
\hline $\begin{array}{l}\text { Not keeping the class schedule and some classes } \\
\text { overlapping }\end{array}$ & 2.25 & 1.46 & 63.9 & 13.7 & 22.4 \\
\hline $\begin{array}{l}\text { Teaching materials are protected and do not let } \\
\text { printing or editing }\end{array}$ & 2.25 & 1.29 & 60.9 & 21.0 & 18.1 \\
\hline $\begin{array}{l}\text { Difficulty to fulfil assignments due to online } \\
\text { learning conditions (e.g. large images or pictures } \\
\text { on screen) }\end{array}$ & 3.09 & 1.47 & 37.9 & 19.8 & 42.3 \\
\hline $\begin{array}{l}\text { Having to buy specific material for academic } \\
\text { assignments (e.g. printer, scanner) }\end{array}$ & 2.33 & 1.46 & 61.5 & 14.7 & 23.8 \\
\hline Diversity of online learning platforms by teachers & 3.03 & 1.42 & 39.3 & 19.0 & 41.7 \\
\hline
\end{tabular}

\subsection{Comparing personal and teaching factors affecting students' online learning}

A paired-samples t-test was conducted to compare students' perceptions with regard to the factors that most affected their online learning. There was a statistically significant difference between personal and teaching factors $(t(495)=-14.420, p<.001)$. According to the participants, they had to struggle more with teaching factors $(M=3.18, S D=0.80)$ than with personal factors $(M=2.69$, $S D=0.85)$ during their online learning. The Cohen's $d$ statistic $(0.63)$ indicated a medium effect size.

\section{Discussion and conclusions}

The purpose of this research study was to explore university students' experiences of online learning during the COVID-19 pandemic. This work presents the preliminary findings with regard to the availability and use of electronic devices and the personal and teaching factors that could have affected their learning and academic outcomes.

Access to technology did not seem to be a problem for participants since the great majority reported that they had the necessary electronic devices to follow online learning such as laptops, webcams and headphones. According to the National Institute of Statistics (INE, 2020), more than 90\% of Spanish households have access to the Internet and almost the same percentage have computers and this fact was reflected in university students' responses.

However, participants had to struggle with personal factors that could have affected their learning. For instance, combining online learning with family responsibilities was reported by almost half of the students. In addition, the uncertainty of the pandemic crisis and the unexpected and sudden changes in daily lives had consequences on the adaptability of $40 \%$ of the participants. In this sense, the study conducted by Besser, Fleet and Zeigler-Hill (2020) confirmed that students had more pervasive negative reactions to online learning than to a more typical face-to-face learning condition (e.g. higher levels of stress and isolation, negative mood, less motivation and performance). Likewise, the lack of experience in online learning of the majority of the students could have led to some of them to express difficulties to adapt to online learning.

But the greatest complaints were concerning teaching factors. Similarly to other studies, students had to struggle with too much autonomous learning and the lack of lesson explanations, the difficulty to concentrate during live streaming classes, a feeling of being abandoned by their educators and the lack of interaction and feedback (Adnan \& Anwar, 2020; Castellano Gil, Carrera Flores, \& Crespo Crespo, 2020).

Findings from this study highlight the need of putting into practice the best teaching strategies during an emergency remote teaching situation (Bozkurt \& Sharma, 2020; Hodges, Moore, Lockee, Trust, $\&$ Bond, 2020), especially with regard to student-teacher interaction. Instructors need to set the conditions for a meaningful relationship and communication with their students in order to create the best online environment in which to learn. The lessons learnt from this crisis will help to take better instructional decisions in the future. 


\section{References}

Adnan, M., \& Anwar, K. (2020). Online learning amid the COVID-19 pandemic: students' perspectives. Journal of Pedagogical Sociology and Psychology, 2(1), 45-51. http://www.doi.org/10.33902/JPSP.202020261309

Álvarez-Flores, E. P., \& Núñez-Gómez, P. (2019). Efectividad del uso de herramientas digitales en el desarrollo académico de estudiantes universitarios [Effectiveness of the use of digital tools in the academic development of university students]. In S. Amavizca Montaño (Ed.), Alfabetización informacional para la gestión del conocimiento en la universidad (pp. 49-74). Sonora: Universidad Estatal de Sonora.

Amhag, L., Hellström, L., \& Stigmar, M. (2019). Teacher educators' use of digital tools and needs for digital competence in Higher Education. Journal of Digital Learning in Teacher Education, 35(4), 203-220. https://doi.org/10.1080/21532974.2019.1646169

Besser, A., Flett, G. L., \& Zeigler-Hill, V. (2020). Adaptability to a sudden transition to online learning during the covid-10 pandemic: understanding the challenges for students. Scholarship of Teaching and Learning in Psychology. Advance online publication. http://dx.doi.org/10.1037/st10000198

Bossolasco, M., Chiecher, A., \& Dos Santos, D. (2020). Perfiles de acceso y apropiación de TIC en ingresantes universitarios. Estudio comparativo en dos universidades públicas argentinas [Profiles of access and appropriation of ICT in freshmen students. Comparative study in two Argentine public universities]. Píxel-Bit. Revista de Medios y Educación, 57, 151-172. http://dx.doi.org/10.12795/pixelbit.2020.i57.06

Bozkurt, A., \& Sharma, R. C. (2020). Emergency remote teaching in a time of global crisis due to CoronaVirus pandemic. Asian Journal of Distance Education, 15(1), i-vi. https://doi.org/10.5281/zenodo.3778083

Cabero-Almenara, J., \& Llorente-Cejudo, C. (2020). Covid-19-transformación radical de la digitalizacion en las instituciones universitarias [Covid-19: radical transformation of digitization in university institutions]. Campus Virtuales, 9(2), 25-34.

Castellano Gil, J. M., Carrera Flores, R., \& Crespo Crespo, W. (2020). Educación on line en tiempo de Covid-19: percepción en estudiantes de la Universidad Católica de Cuenca (Ecuador) [Online education in COVID-19 times: perception in students from the Catholic University of Cuenca (Ecuador)]. Revista de Historia, Patrimonio, Arqueología y Antropología Americana, 3, 149-175. https://doi.org/10.5281/zenodo.4066073

Creswell, J. W. (2015). Educational research: planning, conducting, and evaluating quantitative and qualitative research (5th ed.). Upper Saddle River (NJ): Pearson.

Hodges, C., Moore, S., Lockee, B., Trust, T., \& Bond, A. (2020, March 27). The difference between emergency remote teaching and online learning. EDUCAUSE Review. Retrieved from https://er.educause.edu/articles/2020/3/the-difference-between-emergency-remote-teaching-andonline-learning\#fn8

Instituto Nacional de Estadística. (2020). Equipamiento y uso de TIC en los hogares. Año 2020 [Equipment and use of ICT in households. Year 2020]. Retrieved from https://www.ine.es/dyngs/INEbase/es/operacion.htm?c=Estadistica_C\&cid=1254736176741\&men $\mathrm{u}=\mathrm{ultiDatos} \& \mathrm{idp}=1254735976608$

Portillo, J., Garay, U., Tejada, E., \& Bilbao, N. (2020). Self-Perception of the Digital Competence of Educators during the COVID-19 Pandemic: A Cross-Analysis of Different Educational Stages. Sustainability, 12(23), 10128. https://doi.org/10.3390/su122310128

United Nations Educational, Scientific and Cultural Organization. (2020). COVID-19 impact on education. Retrieved from https://en.unesco.org/covid19/educationresponse

World Health Organization. (2020). Coronavirus Disease (covid-19) pandemic. Retrieved from https://www.who.int/emergencies/diseases/novel-coronavirus-2019 